DOI: $10.1515 /$ hssr -2015-0025

HSS IV.3 (2015)

\title{
Unveiling the Individual Memory of War in the Work of Maïssa Bey
}

S. Seza Yilancioglu*

Galatasaray University, Istanbul, Turkey ${ }^{* *}$

\begin{abstract}
This paper is interested in the individual memory of wars in Maïssa Bey. The writer devoted her two books to the wars in Algeria - they were written to be adapted to the theatre: Entendez-vous dans les montagnes... (2002) and Pierre Sang Papier ou Cendre (2008). In Entendez-vous dans les montagnes..., the memory in question is that of the War of Independence against the colonization during the years 1956-1962, while Pierre Sang Papier ou Cendre addresses the French colonization that lasted 132 years, from 1830 to 1962. In other words, the first relies on individual and collective memories, while the second concerns especially the collective memory.
\end{abstract}

Keywords

Algerian literature, Maïssa Bey, Individual / collective memories, Memory of wars, Colonization.

\section{Introduction}

The French-speaking Algerian women's literature is marked by the historical context since the 1980s. Writers like Malika Mokadem, Assia Djebar and later, Maïssa Bey, dare to assert themselves in a patriarchal society, by "opting for an exclusively feminine voice". Among these writers, Assia Djebar, mother-founder of the following generation, and

\footnotetext{
${ }^{*}$ Faculty of Arts and Sciences, Galatasaray University, Yıldız Mh., Çırağan Cd No.102, Beşiktaş, Turkey; seza.yilancioglu@gmail.com

** This study was conducted with the financial support of the Centre of scientific research projects Galatasaray University.
} 
elected to the French Academy in 2005, tells her story from a hybrid environment between reality and fiction, including a historian vision of the colonization of Algeria in 1830, especially in L'amour, la fantasia (1985). It evokes the important dates of both the collective and the individual memory. Through this, its readership is made witness to the after-effects of the colonization of the Algerian people.

Before the end of the decade of 1990, another female voice will rise from the Algerian soil: the voice of Maïssa Bey, whose birth and childhood were marked by the War of Independence (1956-1962) in Algeria. She walked in the footsteps of Assia Djebar and, just like her model, she was pushed towards the French language by her father, who was teaching it to indigenous children. Maïssa Bey, unlike Assia Djebar or Leila Sebbar - daughter of a schoolteacher father as well - became a French writer without ever leaving Algeria.

Our article is interested in the individual memory of wars in Maïssa Bey. The writer devoted her two books to the wars in Algeria -written to be adapted to the theatre: Entendez-vousdans les montagnes... (2002) and Pierre Sang Papier ou Cendre (2008).In Entendez-vousdans les montagnes..., the memory in question is that of the War of Independence against the colonization during the years 1956-1962, while Pierre Sang Papier ou Cendre addresses the French colonization that lasted 132 years, from 1830 to 1962. In other words, the first relies on individual and collective memories, while the second concerns especially the collective memory.

In Entendez-vousdans les montagnes..., Maïssa Bey speaks for the first time of her father, using paratextual elements, such as a picture of him and authentic ancillary documents - a certificate of nationality, a certificate of good conduct and morals, a postcard addressed to her sister, written by her father - which justify a certain reality in Maïssa Bey's life and help to anchor the story in this tangible reality where her father joins the FLN for the liberation of the country. His political commitment cost him dearly, as he will end up being tortured and killed in 1957 by French soldiers in Boghari, ten years after becoming a teacher.

To honour the memory of her father, Maïssa Bey has never applied for French naturalization.

The title of the book evokes the hybridization between two cultures, Arabic and French, as Entender-vous dans les montagnes... is the contraction 
HSS, vol. IV, no. 3 (2015): 73-89

of the beginning of the fifth verse of the Marseillaise: "Entendez-vous dans nos campagnes", which translates to "Do you hear in the countryside" and a patriotic Algerian song called "Min Djebelina": "De nos montagnes est venu le chant de la liberté, qui appelle l'indépendance", which translates to "From our mountains came the song of freedom, calling for independence." This patriotic song uses the French national anthem, derived from the French Revolution. The title reconstructs the painful past, intimately linking the two countries with these two song fragments from the French Revolution and the country's history.

Other signs are very important, such as the dedications and the epigraph: the double dedication,to the father, "celui qui ne pourra jamais lire ces lignes" (the one who will never read these lines), and " $\grave{A}$ mes fils"(To my sons), proves that the book stands somewhere between testimony and transmission, as in the tradition of the world of Islamthe sons are in charge of carrying the family burden.

As for the epigraph, it is a quote from a poem by Victor Hugo:

Ô soldats dont l'Afrique avait hâlé la joue

N'avez-vous donc pas vu que c'était de la boue.

Qui vous éclaboussait ? ${ }^{1}$

(O! Soldiers, Africa has tanned your cheeks

Have you not seen that it was mud

Who splashed you?)

In the $19^{\text {th }}$ century, Africa was a virgin land, ready to be cleared, that was coveted by Europeans for the use all its resources. The epigraph implicitly announces the main theme of the story: "a war in Africa."

The fate of her father is told in a theatrical atmosphere woven into a context that is both real and fictional. Theatricality is constitutive of the story structure.

\section{The storyline}

The plot takes place in the compartment of a train that goes to Marseille (the city name is not explicitly specified, but can be guessed), between three characters whose destinies will cross in particular 
HSS, vol. IV, no. 3 (2015): 73-89

circumstances. First, a woman (who is from the same generation as the author), then a man in his sixties - a physicist and a former military peacekeeping operation, from Boghari (the town where Maïssa Bey's father worked before being killed) - and whose silhouette reminds the woman of her father. The woman fled her country, Algeria, to escape the terrorist groups of the 1990s. During the dark decade in Algeria, there were many massacres and events that pushed the narrator into a painful meditation.

Finally, Marie, the third person, is a girl, "blonde and smooth, in jeans and sneakers, confident, visibly self-assured", granddaughter of a piednoir. As Colette Valat explained: “... dramatization also signals the will of Maïssa Bey to transform into fiction the scene that belongs to her memory and to take distance with respect to her emotions"..(Valat, 2009: 22)

In Entender-vousdans les montagnes..., the war for national liberation of Algeria is questioned again 40 years later, through a personal memory that has not yet healed; where the murder of the writer's father emerges in an imaginary journey in one of the train compartments. This fictionalised closed door allows Maïssa Bey to confront the daughter of the victim (fatherless) with his killer: the French military man.

The narrative is built on a double axis silence/speech. First of all, travellers are silent; silence, as denial and as protection, weighs throughout the narrative. This recalls the 40 years of silence between the two parties (France/Algeria). Then, the man wants to talk and seeks to build and open a dialogue. Finally, the woman begins to speak and her words bring the man back to his shady past. He explores fragments of memories related to "peacekeeping operations" in which he participated, alongside the French army and that have been haunting him for so long.

Officially, this father was killed ${ }^{2}$ while trying to escape from the camp where he was held and the author can only visualize in her mind a few fragments of her father.

Gradually, as the train moves to Marseille, the personal history of the victim comes to the surface. 
HSS, vol. IV, no. 3 (2015): 73-89

\section{A story between reality and fiction}

The photograph placed at the beginning of the story is an authentic document and establishes the tangible link between the author and the narrator, thus emphasizing the autobiographical pact. But the story is written in the third person: "she". The writer uses the personal pronoun ("she") to let the character speak, because she could not tell this cruel history with her own mouth. The transition from "I" to "she" allows her to fictionalize the event.

In fact, reading indeed confirms that it is an autobiography or a selffiction, as defined by Serge Dubrovsky, because "she" corresponds to the author herself. The use of "she" allows her, first, to take the necessary distance from her characters and also to become the spokesperson of her generation. Thus the writer manages to extract, before the end of the story, all that was buried about the death of her father.

Using the process of "autobiographical impersonal" writing, the author delegates the narration to an omniscient narrator who travels in the spirit, through the experiences - as much as the writer allows it - of each of the three characters. It happens several times in the text that "she", the character mediated by the narrator, turns quietly into an "I", reinforcing this equation that "I-she" and narrator-author share the same identity.

The passages where the sliding takes place the "she" to the "I" are the following:

This obsession... the question often arises when she faces men of this age, a question she always tries to repress. These wrinkles, just stigmata on his lips. My father would have roughly the same age. No, he would be even older ... (Maïssa Bey, 2010: 19-20)

She looks up and looks. Her address from there, her only real address, still on the label attached to the bag. Visible. Her name too. He knows what my name is where I come from, maybe... but yes, I'm just passing through. (Maïssa Bey, 2010: 31). ${ }^{3}$

In support of the above quotations, to complete this contribution, we want to mention that autofiction is like "an intimate story whose author, 
HSS, vol. IV, no. 3 (2015): 73-89

narrator and protagonist share the same nominal identity and in which the text and/or peri-text indicates that it is a fiction", as defined by Alexandre Sicart (Sicart, 2005: 14) in the thesis entitled Autobiographie, Roman, Fiction (apud Mokaddem, 2009: 220).

Maïssa Bey makes her writing process very clear:

"I had to imagine a place, a "lieu de passage", characters, a circumstance that would put these characters into motion, protagonists of a story they will gradually regain as they advance in their journey (...) in order to protect me, to take some distance, which could not have been done if I had decided to stage an external narrator. Regardless of whether she is my age or if we find in her fragments of my story, I kept my distance thanks to the grammatical resources of the language. It is only under these conditions that I was able to start writing about the death of my father.",

Many descriptions of places, characters and scenes are taken directly from the reality of the national liberation war, scattered throughout the text, and the memoirs of Benjamin Stora (3 volumes) justify the names of places and dates noted in the narrative.

November 1956. Arrival in the port of Algiers. The "city of Algiers" is docked. The crossing was rough. One by one, they emerge from the hold, get off the boat, still on wobbly legs (...). Pacification. Your mission, our mission: to quell the rebellion! (...) Algeria is a French department, who could doubt that? (Maïssa Bey, 2010: 58-59)

This process follows the idea of Paul Ricoeur: "the relationship between reality and fiction will continue to torment us to the stage of historian representation of the past. This means that the first component of the testimony has its weight. It is from this articulation that a suspicion falls into place." (Ricoeur, 2002: 203-204) The "suspicion" concerns the veracity of the historical narrative based on personal testimony, and yet it is this personal story that gives birth to the historical narrative. In the text of Maïssa Bey, it is the "fictional" story that is accredited by the personal narrative.

The plot ends at the train station: 
HSS, vol. IV, no. 3 (2015): 73-89

Something has settled in her (...). She told herself that nothing resembles her childhood dreams, that the executioners have human faces, she is sure of that now, they have human hands, sometimes even the human reactions and there is nothing to distinguish them from the others. And this idea terrifies her a little more. (Maïssa Bey, 2010: 75) ${ }^{6}$

The writer reconstitutes her suspicions about the assassination of her father.

Gradually, as the narrator's doubts reflect the doubts of the writer and she engages in a conversation with the doctor who was in the French army service in Boghari, her distrust towards the doctor increases. At the end, in Marseille's railway station, on the platform just before they leave, the doctor will say to the woman/the narrator:

- I wanted to tell you... it seems to me... yes... you have the same eyes... the same look as your father. You look a lot like him. (Maïssa Bey, 2010: 77) ${ }^{7}$

Ellipses in the doctor's speech signal the likelihood of the situation, and accredit the assumption that this fiction offers in regards to the possibility that a stranger appears one day to testify before Maïssa Bey of the death of her father.

I leave the floor to Maïssa Bey:

("It took me two years to write a text of about 70 pages. A woman's life, before facing my childhood injuries, a time for resilience. How long does it take for us to finally agree to set our eyes on all the scars inflicted, all the injuries suffered so that they never can be opened again?") ${ }^{8}$

\section{Pierre Sang Papier ou Cendre}

Pierre Sang Papier ou Cendre, published in 2008, is dedicated to her sister Anissa,who is politically committed to the independence of Algeria. Unlike Entendez-vous dans les montagnes..., it is based on a broader historical background, including the French colonization that took place from 1830 to 1962.

The novel begins with the eyes of a child set on "strange silhouettes that make these still boats (...)" (Maïssa Bey: 2008, 9). This view probably reveals the arrival of the French fleet in the Bay of Algiers: "The White 
HSS, vol. IV, no. 3 (2015): 73-89

City has finally awakened". (Maïssa Bey: 2008, 11) The opening words of the novel remind us of L'Amour la fantasia, written by Assia Djebar and published in 1985.

The dawn of June 13, 1830, at the very moment when the day breaks above the deep shell. It is five in the morning. Before the large fleet that tears the horizon, the city is revealed, in its ghostly whiteness, through a haze of blue and grey. (...) First face to face. The city, sharp landscape and delicate colours, emerges in the role of an Oriental girl immobilized in her mystery. The French Armada will slide slowly in front of her in a sumptuous ballet, from the first hour of the morning to a splashed midi. (Assia Djebar, 1995: 14) ${ }^{9}$

These two excerpts reveal the sensitivity of the female writings on the French colonization of Algeria. Like the work of Assia Djebar, that of Maïssa Bey, a very complex one, is inscribed in a double violence, that of history and that of society. Armed with some pure jewels of historical and individual scenes, historical violence will be restored by the work of writing, because the French language, established in the country by colonization, offers them international recognition.

\subsection{The story of Pierre Sang Papier ou Cendre}

Pierre Sang Papier on Cendre, whose title is borrowed from the famous poem by Paul Eluard, Liberté, announces through the choice of the words "blood" and"ash", the violence in the heart of which hope is served by two children (an Algerian child, the omniscient narrator of the book, and Pierre). It is through the poem Liberté that the writer establishes a conscious historical link between the two occupations, almost a century apart: the occupation of Algeria by the French soldiers and that of France by the Nazis. Liberté, written in 1940 by Paul Eluard, while his country, France, was under the occupation of Germany, reflects the cry of freedom of the French people. Through the verse of this poem, Maïssa Bey recalls the similar cry of the Algerian people that had lasted more than a century.

The opening words of the novel progress slowly, as if it were a play. The French fleet moves toward the coast of El Djazzir. "So that's Africa? That is their new America?” (Maïssa Bey, 2008: 18) 
In this novel, Maïssa Bey embraces with a poetic gesture 132 years of French colonization (1830-1962), delegating the omniscient narration to the eyes of a child, a sentinelle de la mémoire who observes, in the morning of June $14^{\text {th }}, 1830$, the arrival of Madame Lafrance. The latter becomes the main character of the novel. "She (Madame Lafrance) advances, imperious and imperial. (...) It is the freedom guiding the people." (Maïssa Bey, 2008: 25)

The omniscient narrator slips through the eyes of the child in the thought of Madame Lafrance to convey to the reader the vision of the coloniser. The sentinel child will see everything, will hear the cries of men and women in smoky caves, tightening camps, etc. Through the omniscient narrator, as we have witnessed in Entendez-vousdans les montagnes..., the aim of the writer is to depict the violence, the pain, and also the submission and acculturation of a people, which dates back to the 1830s.

\section{Colonization and acculturation}

The novel is a kind of fed indictment of political and literary quotations (Alexis de Tocqueville, Louis Bertrand, Jules Ferry, Charles Baudelaire, Victor Hugo, Guillaume Apollinaire, Guy de Maupassant or Albert Camus). The author quotes the words of Alexis de Tocqueville to better reveal the imperialist power: "We have made the Arab society much more miserable, messier, more ignorant and more barbaric than it was before knowing us". (Maïssa Bey, 2008: 68)

In this novel, Maïssa Bey focuses very cleverly, with a smooth, bright, tight, and squeaky writing on the loss of cultural identity, a strong element of the imperialist power. Acculturation is imposed on the Algerian people through language and teaching. First, Madame Lafrance renames the streets to erase the collective memory.

Finally, Madame Lafrance enters the teaching world to impose her language and culture to indigenous children and instructs them, in the civics lesson, to repeat this phrase written on the board: "I love France, my country." (Maïssa Bey, 2008: 54) Algerian students, despite their initial difficulties in adapting to the French language, "their new language," eventually learn it properly, due to the power and strength of 
HSS, vol. IV, no. 3 (2015): 73-89

Madame Lafrance "They must learn to love France and its language. And through its books."(Maïssa Bey, 2008: 58).

Madame Lafrance also imposes her religion without hesitation, and on the walls of the town halls her motto is engraved in capital letters:

«LIBERTÉ, ÉGALITÉ, FRATERNITÉ » (Maïssa Bey, 2008: 69)

Language and religion are the two strongest entities to reshape identity. For this reason, the imperial power requires both language and religion to clear local identity, the "Algerian identity". To speak French correctly and to prohibit access to the mosque are two indispensable principles which help to create an identical nation and to annihilate it. The mosque will henceforth be devoted to the "God of the Christians." (Maïssa Bey, 2008: 74)

However, with the omniscient narrator, Maïssa Bey describes the different characteristics of a lifestyle between the two peoples; how to dress, eat, walk. The writer lets the narrator speak in order to make us discover the Roumis:

The Roumis like what is firmly implanted in the ground.

The Roumis like what is tall and straight.

The Roumis do not live like them. (Maïssa Bey, $2008: 87)^{10}$

To eat, they sit around a high table, on chairs (...). They drink wine. They do not pray to God in the same way, nor in the same premises, nor in the same language. It is even said that they are not circumcised.

Their women are nothing like the women of his race. They go bareheaded in the streets. They wear short and light dresses, which expose bare arms and legs. They rub shoulders with men, join them in cafes, talking and laughing loudly, shamelessly. (...)

And then the French live in houses, the Arabs in shacks. The Arabs sleep on mats, the French in beds. (Maïssa Bey, 2008: 87-88) ${ }^{11}$

Although Madame Lafrance (La France) imposes her culture and her habits to the Algerian people, a coexistence between the two peoples does not exist yet, despite a century of presence in the territory, and the 
HSS, vol. IV, no. 3 (2015): 73-89

child says: "The school in the village is the only place where the child can approach the French." (Maïssa Bey, 2008: 89)

In Pierre sang Papier ou Cendre, the five key dates in the history of the colonization of Algeriaare outlined: 1830, 1845, 1930 and 19541957. The writer ironically evokes the Centenary of the colonization through the interplay of words and metaphor: "It's the law", uttered by a soldier, catches the attention of the child: "Its laws. It's the law. If Laloi". The child will realize later what was "the law; it is her, it is Madame Lafrance."

The writer examines and interprets the situation of the Algerian people, torn between two cultures, two identities, two civilizations... The two children, the Algerian and his French friend Pierre, carry two innocent viewpoints. They see, hear, understand, discover, decipher, interpret and explain the facts that are happening around them from a perspective that is pure, simple, and naïve, without being influenced by either the imperial force or by the attitude of an assimilated people. Maïssa Bey's choice makes her writing more vivid and her style is reinforced by her tenacity, to transmit a story represented in its exact traits. The main character, "Madame Lafrance", is not random, because "Madame Lafrance" is a common expression in Algeria at the time of colonization to highlight the contempt and disdain of the French towards the Algerian people.

\section{Meeting of the two children: the protagonists}

The child, "la sentinelle de mémoire", tells the story of the colonization from 1830 to 1962, all through this period. The child symbolizes the present, purity, innocence, hope, and the future. The child dialogues with his French classmates to criticize the attitude of the coloniser on the Natives, a century after the French occupation.

Pierre, whose name brings us straight to the title of Paul Eluard's book and poem, is one of the child's classmates. "Pierre" comes from a family of settlers; this means that he is a French citizen, while the "sentinelle de la mémoire" is a boy - whose name is not even mentioned, from an indigenous family. He is barely a French subject. Now, the first boy is named Pierre. This subtle hint nevertheless perfectly underlines the difference between these two communities, French citizen - French 
HSS, vol. IV, no. 3 (2015): 73-89

subject, in the era of colonization. The fact that, under the rules of Islam, male children are usually named after the first name of Mohammed, for the salvation of the Prophet, also denounces the insignificance of the Algerian people against the French. Furthermore, the Algerian child, despite the centennial presence of Madame Lafrance, can finally meet with French at the school of his village.

Pierre lives in the European district. One day, when he goes to see the child's parents, he is welcomed by the smile of the mother and the grandmother. They offer him tea with mint and donuts. Pierre never learned Arabic and feels very sorry not to be able to talk with the family of his friend. He could spend hours watching his mother.

The narrator withdraws to give voice to Pierre, so that he is able to ask his father his own questionsabout education, and especially about the lack of Arabic teaching at school.

His father, surprised by a question that he had never thought of, gives this answer to his son:

Then he told him that here everyone was French because we were in France, and that in France, the only language is French.(...)

He did not understand his explanation. Firstly, because France is another country on the other side of the sea. Here, it is Algeria.

(...) Arabs are simply Arabs. His uncle Fernand, he called them "crouilles", "gooks" or "pups", or even "wogs". Probably to distinguish them from the French or the Europeans.(Maïssa Bey, 2008: 150) ${ }^{12}$

This time, the child asks his mother another question : "Why do we hear that the Arabs are dirty?" (Maïssa Bey, 2008: 150), because in the house of his friend, everything was clean, very clean.

Then, the two children show the centennial celebration. For Pierre, it was a joy "that was sweeping the streets of the horrible noises of war" (Maïssa Bey, 2008: 152). The French “chanted loudly: AL-GÉ-RIEFRAN-ÇAISE” (Maïssa Bey, 2008: 152).

But for the other child, it will be a very unhappy memory. After school, he goes to the market to earn some money. While Pierre is having fun with his parents at the centennial celebration of the colonization, the Algerian child is forced to bring some food to his 
HSS, vol. IV, no. 3 (2015): 73-89

family. The text contains multiple social discrimination traits in French Algeria.

However, the fate of Madame Lafrance will switch, first in November 1954, facing the elusive rebel uprising, and then in May 1957, when the Algerian nationalists will start their war against the French imperial yoke to get both their dignity and freedom back. Men will make a statement of resistance against war:

They will say: we have only one enemy, only one, one that oppresses and robs us of our dignity, of our freedom.

They will say: all those who came to terms with this are our enemies.

They will say: the revolution is underway, nothing should stop it. (Maïssa Bey, 2008: 145) ${ }^{13}$

From this period, Madame Lafrance, who does not like to be spoken to of internment camps or resettlement camps, is divided into two, she is shaken.

The book ends with the departure of the French and the victory of Algeria:

The French in Algeria have only one obsession: to leave. To find refuge in the motherland. (MaïssaBey, 2008: 191)

They have their eyes fixed on the White City that moves away and disappears gradually.

They leave the harbour. Slowly. Very slowly. (Maïssa Bey: 2008, 193) ${ }^{14}$

\section{Conclusion}

Maïssa Bey, following the excellent dramatization of Entendez-vous dans les montagnes..., does it again with Pierre Sang Papier ou Cendre, at the request of the French director Jean-Marie Lejude. The text was written for his theatre company and performed under the title of Madame La France. The narration in Maïssa Bey's work often grazes dramatization and in this form, the writer confronts and crosses the characters to understand, question, and interpret her own past as well as that of her country.

The writer establishes a neutral point of view, choosing an omniscient narrator. The characters express their ideas and feelings from an internal 
HSS, vol. IV, no. 3 (2015): 73-89

point of view and if the narrator wants to make them speak when necessary, he gets into the skin of the characters. Thus, the "interrogation practices and processes" are coming from the memories of the witnesscharacter's or the victims' memories of the colonization and the war in Algeria. By this process, the writing of Maïssa Bey is enriched by two memories: collective and individual.

This shows us that the most basic technique in Maissa Bey's writing is the fragmented narrative. By means of this technique, she seeks the individual truth that emerges from the collective life. For her, memory has a very important function and serves, as explained by Jacques Le Goff, "in saving the past to serve the present and the future". ${ }^{15}$

We conclude with the words of Christiane Achour on Maïssa Bey: "Today and certainly since the late 1990s, Maïssa Bey became a reference in the literature of Algerian women."16

\section{References}

Bey, M. (2010). Entendez-vous dans les montagnes... Editions de l'Aube. coll. L'Aube Poche (first edition 2002)

Bey, M. (2008). Pierre sang papier ou cendre. Editions de l'Aube.

Djebar, A. (1995). L'Amour, la fantasia. Paris: Albin Michel (first edition 1985)

Ricoeur, P. La Mémoire, l'histoire, l'oubli. (2000). Paris: Editions du Seuil, Points, coll. Essais.

Mokaddem, K. (2009). "Les écritures féminines de la guerre d'Algérie : l'exemple de Maïssa Bey". Synergie Algérie, n 5 5. 217-225.

Valat, C. (2009) "La romancière algérienne Maïssa Bey". Horizons Maghrébins Littérature Féminine Francophone avec et autour de Maïssa Bey- $25^{\mathrm{e}}$ année, $\mathrm{n}^{\circ} 60$. Presses Universitaires du Mirail. 10-32.

Valat, C. (2009) “L'écriture le seul territoire où j'arrive à me trouver". Horizons Magbrebins - Littérature Féminine Francophone avec et autour de Maïssa Bey - 25 année, n ${ }^{\circ}$ 60, Presses Universitaires du Mirail. 33-41.

Yllancioglu, S. (2010) «Maïssa Bey : une voix algérienne ». Synergie Turquie. 3. 8996.

\footnotetext{
${ }^{1}$ Quotes from Entendez-vous dans les montagnes... and Pierre Sang Papier ou Cendre are translated into English by Maude Mainguy.

${ }^{2}$ Two years ago, Maïssa Bey learned from an Algerian historian that her father and uncle (brother of her father) suffered a violent torture, and that their bodies
} 
HSS, vol. IV, no. 3 (2015): 73-89

were thrown to the dogs (Maïssa Bey told this story during a literary meeting at the Galatasaray University, on May $\left.22^{\text {nd }}, 2015\right)$.

3 «Cette obsession... la question qu'elle se pose souvent lorsqu'elle se retrouve face à des hommes de cet âge, question qu'elle tente toujours de refouler. Ces rides inscrites comme des stigmates au coin des lèvres. Mon père aurait à peu près le même âge. Non, il serait plus vieux encore... » (Maïssa Bey, 2010 : 1920)

«Elle lève la tête et regarde. Son adresse de là-bas, sa seule véritable adresse, encore sur l'étiquette accrochée à la valise. Bien visible. Son nom aussi. Il sait comment je m'appelle, d'où je viens, peut-être même... mais oui, je ne suis que de passage. » (Maïssa Bey, 2010: 31)

4 «Il m'a fallu imaginer un lieu, un lieu de passage, des personnages, une circonstance qui mettrait en scène ces personnages, protagonistes d'une histoire qu'ils vont retrouver au fur et à mesure qu'ils avancent dans leur voyage $(. .$.$) pour me préserver, prendre de la distance, ce qui n'a pu se faire$ lorsque j'ai décidé de mettre en scène une narratrice extérieure. Peu importe qu'elle ait mon âge, que l'on retrouve en elle les fragments de mon histoire, je l'ai tenue à distance grâce aux ressources grammaticales de la langue. C'est seulement à ces conditions que j'ai pu commencer à écrire sur la mort de mon père. »

5 «Novembre 1956. L'arrivée au port d'Alger. Le "ville d'Alger" est à quai. La traversée a été houleuse. Un à un, ils émergent de la soute, descendent du bateau, les jambes encore flageolantes (...) Pacification. Votre mission, notre mission : mater la rébellion! (...) L'Algérie est un département français, qui pourrait en douter? » (Maïssa Bey, 2010: 58-59)

In her (unpublished) paper entitled "Les cicatrices de l'histoire" presented in 2002 at the Université de Paris Vlll, during a symposium on "La mémoire de la guerre d'Algérie". Cited in Khédidja Mokaddem. op.cit. 222.

${ }^{6}$ "Quelque chose s'est dénoué en elle (...). Elle se dit que rien ne ressemble à ses rêves d'enfant, que les bourreaux ont des visages d'hommes, elle en est sûre maintenant, ils ont des mains d'hommes, parfois même des réactions d'hommes et rien ne permet de les distinguer des autres. Et cette idée la terrifie un peu plus. » (Maïssa Bey, 2010 : 75)

${ }^{7}$ «- Je voulais vous dire... il me semble... oui...vous avez les mêmes yeux...le même regard que... que votre père. Vous lui ressemblez beaucoup. » (Maïssa Bey, 2010: 77)

${ }^{8}$ «Il m'a fallu deux ans pour écrire un texte de 70 pages environ. Toute une vie de femme avant de pouvoir affronter mes blessures d'enfant, le temps de la résilience. Combien de temps faudra-t-il encore pour que l'on puisse enfin 
HSS, vol. IV, no. 3 (2015): 73-89

accepter de poser notre regard sur toutes les cicatrices de toutes les blessures infligées ou subies pour que jamais elles ne puissent s'ouvrir à nouveau? » Maïssa Bey. "Les cicatrices de l'histoire" paper given at the Paris Vll and EHES conference on La guerre d'Algérie dans la mémoire et l'imaginaire, 14 - 16 November 2002, Jussieu, unpublished) cited in Khédidja Mokaddem, op.cit. 222.

${ }^{9}$ " A l'aube de ce 13 juin 1830, à l'instant précis et bref où le jour éclate audessus de la conque profonde. Il est cinq heures du matin. Devant l'imposante flotte qui déchire l'horizon, la Ville Imprenable se dévoile, blancheur fantomatique, à travers un poudroiement de bleus et de gris mêlés. (...) Premier face à face. La ville, paysage tout en dentelures et couleurs délicates, surgit dans un rôle d'Orientale immobilisée en son mystère. L'Armada française va lentement glisser devant elle en un ballet fastueux, de la première heure de l'aurore aux alentours d'un midi éclaboussé. » (Assia Djebar, 1995 : 14)

${ }^{10}$ «Les Roumis aiment ce qui est solidement implanté dans le sol.

Les Roumis aiment ce qui est haut et droit.

Les Roumis ne vivent pas comme eux. » (Maïssa Bey, 2008: 87)

${ }^{11}$ « Pour manger, ils s'assoient autour d'une table haute, sur des chaises (...). Ils boivent du vin. Ils ne prient pas Dieu de la même façon ni dans les mêmes lieux ni dans la même langue. On dit même qu'ils ne seraient pas circoncis.

Leurs femmes ne ressemblent en rien aux femmes de sa race. Elles vont tête nue dans les rues. Elles portent des robes courtes et légères qui exposent aux regards bras et jambes nus. Elles côtoient les hommes, s'associent avec eux dans les cafés, parlent et rient bruyamment, sans aucune pudeur. (...)

Et puis les Français habitent dans des maisons, les Arabes dans des gourbis. Les Arabes dorment sur des nattes, les Français dans des lits. » (Maïssa Bey, 2008: 87-88)

${ }^{12}$ « Puis il lui a répondu qu'ici tout le monde était Français parce qu'on était en France, et qu'en France, la seule langue est le français. » (...)

«Il n'a pas très bien compris son explication. D'abord parce que la France, c'est un autre pays, de l'autre côté de la mer. Ici c'est l'Algérie.

(...) les Arabes sont simplement des Arabes. Son oncle Fernand, lui, les appelle les crouilles, les bougnoules ou bien les ratons, ou bien encore les bicots. Sans doute pour les distinguer des Français ou des Européens. » (Maïssa Bey, 2008: 150)

${ }^{13}$ «Ils diront: nous n'avons qu'un ennemi, un seul, celui qui nous opprime et nous dépossède de notre dignité, de notre liberté.

Ils diront : tous ceux qui pactisent avec celui-là sont nos ennemis. 
HSS, vol. IV, no. 3 (2015): 73-89

Ils diront: la révolution est en marche, rien ne doit l'arrêter. » (Maïssa Bey, 2008: 145)

${ }^{14}$ «Les français d'Algérie n'ont qu'une seule obsession : partir. Trouver refuge au sein de la mère patrie. » (Maïssa Bey, 2008 : 191)

« Ils ont les yeux fixés sur la ville blanche qui s'éloigne et disparaît peu à peu.

Ils quittent la rade. Lentement. Trèslentement. » (Maïssa Bey, 2008: 193)

${ }^{15}$ Le Goff, Jacques (1988) Histoire et mémoire, Paris, Gallimard, Folio Histoire, réédition 2004, p. 177, cited in Khédidja Mokaddem, "Ibid", op.cit. 223.

${ }^{16}$ Algérie Littéraire, côté Femmes : Vingt-cinq ans de recherches féminines (Communication au colloque international : Le "Genre" - Approches théoriques et recherches en Méditerranée - Unité de recherche Femmes et Méditérannée de l'Université de Tunis - Faculté des Sciences Humaines et Sociales, Carthage, Beïtal-Hikma, 15-17 février 2007) cited in Khedidja Mokaddem, Ibid. op.cit. 219.

\section{Biographical note}

S. Seza Yilancioglu is a Lecturer at the Department of French language and literature of Galatasaray University in Istanbul, Turkey. Specialist in contemporary comparative literature, she wrote several articles on Yachar Kemal, Nedim Gürsel, d'Aslı Erdogan, as well as on Assia Djebar, Annie Ernaux or Nina Bouraoui. She has finished a book on the "feminine identity in the Mediterranean hollow", based on texts written by Turkish, Algerian, Francophone and French writers. Her articles on comparative literature are published in Turkey and abroad. Her most recent research focuses on migrant writing.

(Translated from French to English by Maude Mainguy) 